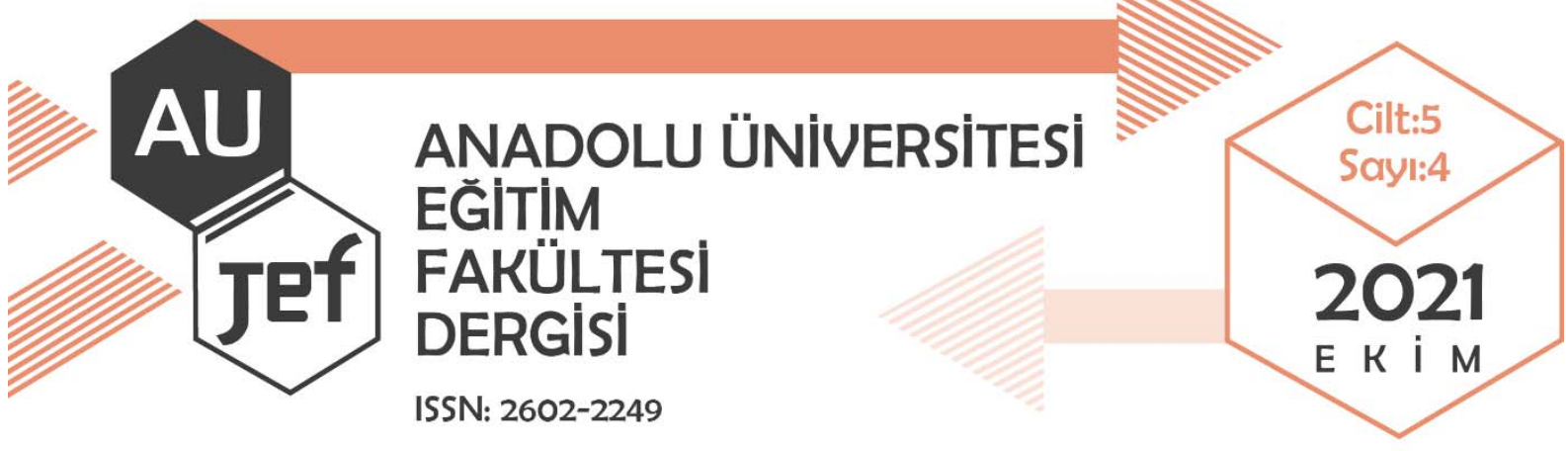

\title{
Erasmus+ Projesinde Gençlik Çalışanı Rolünde Öğretmen Olmak
}

\section{Being a Teacher in the Role of Youth Worker in Erasmus+ Project}

\author{
Mehmet FANSA ${ }^{1}$
}

Makale Türü : Araştırma Makalesi

Başvuru Tarihi : 29.05.2021

Kabul Tarihi: 01.10.2021

Atıf İçin: Fansa, M. (2021). Erasmus+ projesinde gençlik çalışanı rolünde öğretmen olmak. Anadolu Üniversitesi Ĕ̈itim Fakültesi Dergisi (AUJEF), 5(4), 427-446.

ÖZ: Küreselleşmenin etkisiyle insanlar arasındaki bilgi alışverişi artmakta ve uluslararası düzenlenen projeler ile öğrenme hareketliliği hız kazanmaktadır. Uluslararası hareketlilik kapsamındaki etkinlikler değerlendirildiğinde Erasmus projelerinin bu alanda öncü olduğu görülmektedir. Bu projeler, firsat ve imkân eşitliğini sağlamanın yanı sıra Avrupa Birliği’ne üye ve aday ülkelerin eğitim seviyesini de yükseltmeyi amaçlamaktadır. Son yıllarda bu projeler, uluslararası alanda düzenlenen informal öğrenme etkinliklerinin merkezi haline gelmiştir. Türkiye de Erasmus projelerine katılım gösteren ülkeler arasındadır. Türkiye’nin Erasmus kapsamında katılımcı olarak dâhil olduğu projelerden biri de Romanya'da gerçekleştirilen “Listen, Feel, Communicate” [Dinle, Hisset, İletişim Kur] adlı projedir. Projenin katılımcı ülkeleri; İtalya, İspanya, Litvanya, Romanya ve Türkiye'dir. Proje katılımcıları; öğretmenlik ve diğer sosyal bilimler alanlarından mezun olmuşlardır. Araştırma grubu, projedeki beş ülke grubundan seçilen altı öğretmenden oluşmaktadır. Bu araştırma, projeye katılan öğretmenlerin kendilerini gençlik çalışanı olarak nasıl anlamlandırdığını ve projenin mesleki gelişimlerine katkısını betimlemeyi amaçlamaktadır. Bu çalışma, fenomenoloji deseninde nitel bir araştırmadır. Araştırmada bulguları ortaya çıkarmak için içerik analizi yapılmıştır. Araştırma sonucunda katılımcılar, gençlik çalışanı olmayı; gönüllü, eleştirel, hareketli, öz güveni yüksek ve yenilikçi roller ile betimlemiştir. Ayrıca proje sürecindeki deneyimlerin öğretmenlere yeni dil ve eğlenceli öğrenme ortamı sağladığı, öğretmenlerin teknoloji becerilerini geliştirdiği ve informal öğrenme yolu ile proje konusu olan iletişim alanındaki bilgilerini artırdığı sonucuna ulaşılmıştır. Araştırma, uluslararası projelerin artırılmasını, proje kazanımlarının proje sonrasında etkinliklerle yaygınlaştırılmasını ve katılımcıların İngilizce seviyelerinin geliştirilmesini önermektedir.

Anahtar sözcükler: Erasmus, mesleki gelişim, gençlik çalışanı olma

ABSTRACT: With the impact of globalization, the exchange of information between people is increasing and learning mobility is accelerating with internationally organized projects. When the activities within the scope of international mobility are evaluated, it is seen that Erasmus projects are pioneers in this field. In addition to ensuring equality of opportunity and opportunity, these projects aim to increase the level of education of member and candidate countries of the European Union. In recent years, these projects have become the center of informal learning activities organized internationally. Turkey is among the countries participating in Erasmus projects. One of the projects Turkey participated in as a participant in Erasmus is the "Listen, Feel, Communicate" [Dinle, Hisset,

\footnotetext{
${ }^{1}$ Dr., MEB, Hatay İl Milli Eğitim Müdürlüğü, mfansa84@gmail.com, ORCID: 0000-0001-5770-797X
} 
İletişim Kur] project in Romania. The participating countries of the project are Italy, Spain, Lithuania, Romania and Turkey. Project participants majored in teaching and other social sciences. The research group consists of six teachers selected from the groups in the participating countries in the project. This research aims to describe how the teachers participating in the project make sense of themselves as youth employees and contribute to the professional development of the project. This study is a qualitative research in phenomenology design. Content analysis was performed to reveal the findings of the study. As a result of the research, the participants were able to become youth employees, and they were able to play voluntary, critical, active, self-reliant and innovative roles. In addition, it has been concluded that the experiences in the project process provide teachers with a new language and fun learning environment, improve the technology skills of teachers and increase their knowledge in the field of communication which is the subject of the project through informal learning. The research recommends increasing international projects, disseminating project achievements with post-project activities, and improving participants' English levels.

Keywords: Erasmus, professional development, becoming a youth worker 


\section{GíRiş}

Küreselleşme, kişilerin ve bağlı oldukları kültürlerin hareketliliği sonucunda dünya görüşlerinin alışverişinden doğan dinamik bir süreçtir. Küreselleşme, ekonomik olduğu kadar teknolojik ve kültüreldir. Günümüzde Avrupa'nın her yaş grubu katılımcıyı dâhil ederek gerçekleştirdiği hareketlilik de küreselleşmenin bir yansımasıdır. Bu hareketlilik ile Avrupa ülkelerinin eğitsel açıdan mesleki gelişimi, eğitim alanındaki firsat ve imkân eşitliğini sağladığı düşünülmektedir. Orta Çağ'dan beri, alimler uluslararası hareketlerle seyahatler etmiş ve birbirleriyle fikir alışverişinde bulunarak meslektaşları ile birlikte çalışmışlardır. Bu nedenle, yükseköğrenimin ve araştırmanın uluslararası bir boyuta taşınması 20. yüzyılın bir icadı olarak değerlendirilmektedir (Cervelló Collazos ve Guardia González, 2008). Bu araştırma, katılımcıların Erasmus+ kapsamında gerçekleştirilen projeler ile farklı kültürleri tanıma, ülkelerin eğitim sistem ve yöntemleri hakkında bilgi sahibi olma biçiminde sonuçlarını ortaya konmuştur. $\mathrm{Bu}$ nedenle Erasmus projelerinin katılımcıların yaşamlarındaki yansımalarının araştırılması, öğretmen veya öğretmen adaylarının kişisel ve mesleki gelişimleri bağlamında önemli araştırma konuları olarak görülmektedir.

\subsection{Erasmus Programı}

Uluslararası hareketlilik 1980'lerde alanında başarılı öğrenciler için ortaya çıkmıştır (Wachter, 2003). 1990'larda yükseköğretim kurumları daha fazla öğrencinin bu haktan yararlanması amaciyla uluslararası ve Avrupa faaliyetlerine başlamıştır. Sokrates programının (LLP'nin eski programı) bu hareketi genişletmesinde önemli bir rol oynadığı bilinmektedir (Maiworm, 2001). Lizbon toplantısında (2000) Avrupa'nın 2010 yılına kadar "Dünyanın en dinamik bilgiye dayalı ekonomisi" haline getirilmesi amaçlanmıştır (Sakar, 2009). Bu amacın gerçekleşmesi, bilginin ekonomik güç olarak kullanılabilmesi de bilginin paylaşılmasını kısaca küreselleşmesini gerekli kılmıştır. Gerçekleştirilen Erasmus programları ile bilginin ülkeler arası dolaşımı hız kazanmıştır. Bu dolaşım öyle artmıştır ki Erasmus 2013 yılında sadece yüksek öğrenim öğrencilerini göz önünde bulundurarak üç milyon katılımcıya ulaştı̆̆ 1 için "Avrupa Birliği'nin 'amiral gemisi' eğitim programı olarak tanımlanmıştır (Vossensteyn vd., 2010).

Küreselleşme çağında eğitim de diğer sosyal alanlar gibi küreselleşmektedir. Eğitimin küreselleşmesinde eğitim ve öğretim faaliyetlerinin sınır ötesine taşınması önemlidir. Absalom (1990), öğrenci, öğretmen, müfredat veya öğretim/öğrenme materyallerinin diğer ülkelere ulaşmasıyla küreselleşmenin başlayacağını savunmaktadır. Günümüzde öğrenme hareketliliğini sağlayan projelerden biri de Erasmus kapsamında düzenlenmektedir. Bu hareketlilikle Avrupa Birliği’ne [AB], üye ülkelerin eğitim-öğretim düzeyini yükseltmek, kapasitesini geliştirmek, teşvik etmek ve güçlendirmek amaçlanmaktadır (European Commission Education \& Training, 2013). Erasmus Programının, genç ve yetişkinlere proje çıktıları ile yarar sağladığı düşünülmektedir. Küresel rekabet, uluslararası iş birliği gerektiren projelerin önemini artırmaktadır. Bu projelerin daha verimli gerçekleşmesi için projeye olan ilginin de son yıllarda arttığı görülmektedir. Özellikle yükseköğretimde Bologna Deklarasyonu (1999) ve Lizbon Stratejisi (2000) öğrenci ve öğretim elemanlarının hareketliliğini de kapsayan ve küreselleşmeyi hızlandıran öncü politika çalışmalardır (Bologna Declaration, 1999; Jones, 2005; Pépin, 2007). Bu düzenlenmeler ile $A B$, üye ülkelerin kendi yerel eğitim politikalarını kabul etmiş ve ortak hedeflere ulaşmak için çerçeve çizmiştir (James, 2013). AB ülkeleri, proje hareketliliği ile yaşam boyu öğrenme ve hareketliliğini gerçekleştirmeyi, eğitim ve öğretimde kaliteyi yükseltmeyi ve etkinliğini artırmayı, eğitimin tüm basamaklarında girişimciliği de içinde barındıran, eşitlik, sosyal bağlılık ve etkin vatandaşlığı teşvik etmeyi, yaratıcılık ve yenilikçiliği artırmayı amaçlamaktadır (EU Council, 2009). 


\subsubsection{Erasmus+ Bireylerin Ö̆̆renme Hareketliliği}

Gelişen ve değişen dünyada eğitim alanındaki yenilikler ve iş birliğine dayalı projeler de hızla yaygınlık kazanmaktadır. $B$ u projeler ve örgütlenmeler içinde $A B$ eğitim programlarının rolü büyüktür. Avrupa Birliği tarafindan yürütülen Eğitim ve Gençlik Programları bu programlardan biridir. Erasmus Projeleri kapsamında genç ve yetişkinler projenin ev sahibi oldukları ülkelere "Youth worker" [Gençlik çalışanı] olarak katılmaktadır. Erasmus programında, ev sahibi ve ev kurumlarındaki akademik ve idari destek ile proje katılımcılarının süreçte etkili öğrenmeler gerçekleştirmesi hedeflenmektedir (Maiworm, 2001). Gençlik çalışanı; kişisel, mesleki ve eğitimsel gelişimlerini informal eğitim yoluyla kolaylaştırmak veya hızlandırmak için diğer akranları ile birlikte çalışan kişi olarak tanımlanabilir. Öğrenciler, eğitmenler veya eğitim-öğretim ile ilgili tüm personel gruplarına yönelik gerçekleştirilen hareketlilik faaliyetlerinin sonucunda aşağıdaki kazanımlarından birini veya birkaçını sahip olması beklenmektedir:

- Meslek profillerine (öğretim, eğitim, gençlik çalışmaları vb.) bağlı gelişmiş yetkinlikler,

- Ülkeler arasında eğitim, öğretim veya gençlik işlerinde uygulama, politika ve sistemlerin daha geniş anlaşılması,

- Eğitim organizasyonlarında modernizasyon ve uluslararası açılım açısından değişiklikler,

• Örgün ve yaygın eğitim, mesleki eğitim ve işgücü piyasası arasındaki bağlantıların daha iyi anlaşılması,

- Öğrenciler, stajyerler, çıraklar, öğrenciler, yetişkin öğrenciler, gençler ve gönüllüler lehine çalışmalarının ve faaliyetlerinin daha kaliteli olması,

- Sosyal, dilsel ve kültürel çeşitliliğe daha fazla anlayış ve duyarlılık,

- Dezavantajlıların ihtiyaçlarını karşılama yeteneğinin artması,

- Mesleki ve kariyer gelişimi için artan firsatlar,

- Gelişmiş yabancı dil ve dijital yetkinlikler;

• Günlük işlerinde artan motivasyon ve memnuniyet (EU Programme-Guide, 2021).

Yaşam boyu öğrenme hareketlilikleri son yıllarda artış göstermiştir. Öğrenci ve öğretmenlerin öğretimi zor olan konularda farklı uluslarla bir arada ve yeni bakış açısı kazanarak yaptıkları çalışmalar kültürlerin de etkileşimini sağlamaktadır (Diana vd., 2014; Göksu, 2011; Teichler, 2001; Vural, Polatoğlu ve Griffith, 2013). 21. yüzyılda bilgi ekonomisini esas alan bu çaba, öğrenme hareketliliğinin de farklı konularda gerçekleşmesini sağlayarak disiplinler arası eğitimleri kapsamıştır (Gibbons, 1998). Öğrencilerin ve akademik personellerin uluslararası hareketlilik kapsamında akademi ve kültürel deneyimleri yansıtan çalışmalar da bulunmaktadır. (Ersoy ve Günel, 2011; Ersoy ve Öncül, 2017; Kasapoğlu-Önder ve Balc1, 2010; Özdem, 2013; Yağc1 vd., 2007; Yücel, 2013). Bu çalışmalar da katılımcılar akademik kazanımlar ve dil konusundaki ilerleme sağlamış ve farklı kültürlerle etkileşimlerini artırmışlardır. Öğrenme hareketliliği programlarına katılan personellerin bu etkinliklerden olumlu dönüt aldığı görülmektedir. Demir ve Demir (2009), Erasmus+ kapsamında 12 öğretmen adayının eğitimlerinin bir bölümünü yurtdışında alarak yabancı dil seviyelerini geliştirdikleri sonucuna ulaşmışlardır. Ünlü (2015) de araştırmasında Erasmus+ programına öğretmen adaylarının katılma sebebinin "yabancı dili geliştirmek olduğunu belirtmektedir. Benzer biçim de Ersoy (2013) da Erasmus + programı ile 6 öğretmen adayının yabancı dil yeterliliklerini geliştirdiği sonucuna ulaşmıştır.

Anadolu Üniversitesi Ĕ̌itim Fakültesi Dergisi (AUJEF), 5(4), 427-446. 
Katılımcıların dâhil oldukları "Listen, Feel, Communicate" projesi, proje ortaklarının ihtiyaçlarının farkında olması sonucunda gerçekleşmiştir. Proje, Romanya ev sahipliğinde İtalya, İspanya, Litvanya, Romanya ve Türkiye'nin katılımı ile gerçekleşmiştir. Her ülke grubundan beş kişi ülkesini temsil etmek üzere projeye katılmıştır. "Dinle, Hisset, İletişim Kur", adlı proje gençlik çalışanları arasında gelişmeyi amaçlayan, farklı iletişim türlerinde bilgi ve becerilerini geliştiren (sözel, sözel olmayan, iddialı, şiddet içermeyen), yaygın eğitim yönteminin hedef gruplarına uyarlanmasını sağlayan bir kurs olarak düzenlenmiştir. Yapılan araştırmalar değerlendirildiğinde çalışmaların çoğunun ya öğretmen adayları ya da öğretim elemanları ile yapıldığı görülmüştür. Alanyazında farklı araştırma grupları ile bu çalışmaların tekrarlanması ve mesleğini icra eden öğretmenlerin de proje deneyimlerinin betimlenmesi gerekli görülmüştür. $\mathrm{Bu}$ doğrultuda, araştırmada Erasmus + Bireysel Öğrenme Hareketliliği Projesine katılan öğretmenlerin deneyimleri betimlenmeye çalışılmıştır.

\subsection{Araştırmanın Amacı}

Araştırma, Erasmus+ kapsamında gerçekleştirilen "Listen, Feel, Communicate" projesine farklı ülkelerden katılan öğretmenlerin uluslararası deneyimlerinin anlaşılmasını amaçlamaktadır. Bu amaç doğrultusunda aşağıdaki sorulara yanıt aranmıştır:

- Katılımcılar, "gençlik çalışanı olma" rolünü nasıl betimlemektedir?

- Katılımcılar, projenin mesleki gelişimlerine katkısına ilişkin ne düşünmektedir?

\section{YÖNTEM}

$\mathrm{Bu}$ çalışma, nitel araştırma yöntemlerinden fenomenoloji deseni ile tasarlanmıştır. Bu desende yaşamımızdaki durumlar, deneyimler ve olaylar gibi farkında olduğumuz ama detaylı ve derinlemesine bir görüşe sahip olmadığımız olgular incelenmektedir (Yıldırım ve Şimşek, 2013). Bu desen ile bir araştırmaya katılan katılımcıların deneyimleri ve bu deneyimlere dayalı olarak olgu ve olaylara yükledikleri kişisel anlamlar incelenmektedir (Akturan ve Esen, 2008). Araştırmada, projeye katılan öğretmenlerin deneyimlerine yükledikleri anlamlar incelenmiş ve araştırma yayın etiğine uygun biçimde gerçekleştirilmiştir.

\subsection{Katılımcilar}

$\mathrm{Bu}$ araştırmada, katılımcıların seçiminde farklı ülkelerde görev yapan öğretmenler belirleyici olmuştur. Araştırma grubunun belirlenmesinde benzeşik örneklem yöntemi tercih edilmiştir. Benzeşik (homojen) örneklem yönteminde küçük ve homojen bir örneklem ele alınarak detaylı olarak çalışılmaktadır (Neuman, 2014). Araştırmaya; İspanya'dan iki, İtalya, Litvanya, Romanya ve Türkiye'den bir öğretmen olmak üzere altı öğretmen katılmıştır. Katılımcıların kod isimleri, ülkeleri ve mesleki deneyim süreleri aşağıda gösterilmiştir.

Tablo 1: Araştırmanın katılımcıları, ülkeleri ve mesleki deneyim süreleri

\begin{tabular}{llc}
\hline Katılımcıların kod isimleri & Ülke & Mesleki Deneyim Süresi (Yıl) \\
\hline Angela & İspanya & 3 \\
\hline
\end{tabular}


Tablo 1 (devamı). Araştırmanın katılımcıları, ülkeleri ve mesleki deneyim süreleri

\begin{tabular}{llc}
\hline Katılımcıların kod isimleri & Ülke & Mesleki Deneyim Süresi (Yıl) \\
\hline Laura & İspanya & 2 \\
Marco & İtalya & 4 \\
Hasan & Türkiye & 13 \\
Constantin & Litvanya & 3 \\
Paul & Romanya & 5 \\
\hline
\end{tabular}

Katılımcılar, araştırmaya gönüllü olarak katılmış ve araştırmacı, katılımcıların gizliliğini sağlamak amacıyla katılımcıları kod isimleri ile betimlemiştir.

\subsection{Verilerin Toplanması, Analizi ve Yorumlanması}

Araştırma verileri, yarı-yapılandırılmış görüşmelerle toplanmıştır. Görüşmeler, nitel araştırmalarda "amaçlı bir sohbet" olarak nitelendirilmektedir (Smith, Flowers ve Larkin, 2009). Araştırmacılara esneklik, etkileşim ve ek sorular yardımıyla derinlemesine irdeleme olanağı sunan görüşme tekniği, katılımcıların deneyimlerini ve anlamlarını ortaya çıkarmaya yardımcı olmaktadır (Yıldırım ve Şimşek, 2013). Araştırma süreci Şekil 1'de verilmiştir.

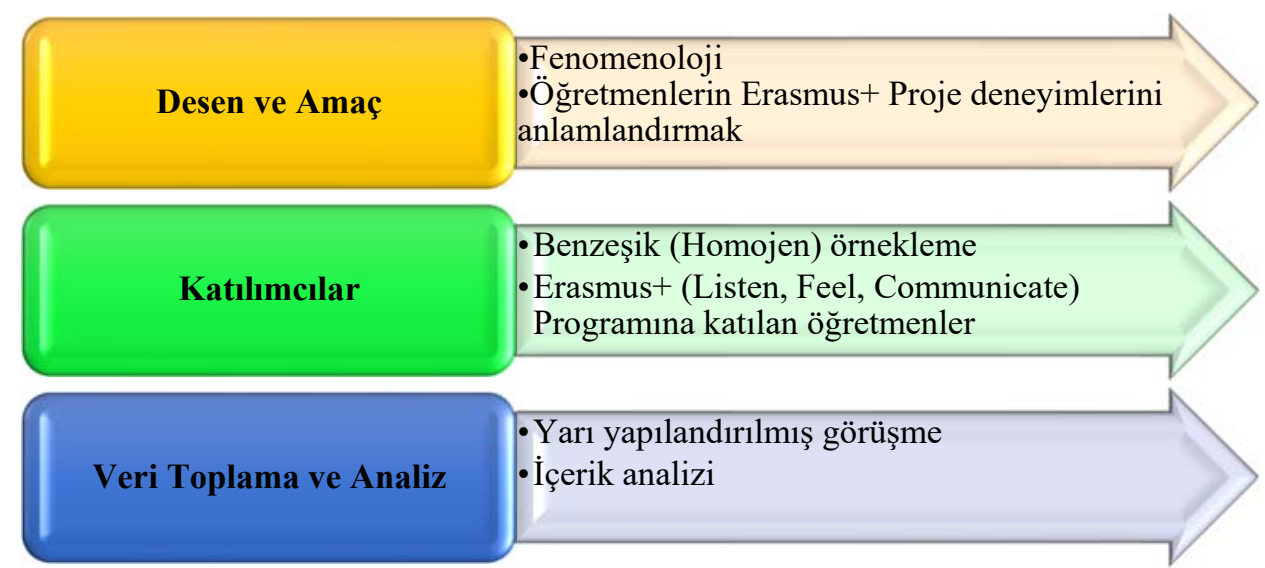

Şekil 1: Araştırma süreci

Araştırmacı, katılımcılarla birebir görüşerek verileri toplamıştır. Araştırma sorularına verilen İngilizce cevapların tek tek Türkçe çevirileri yapılmıştır. Katılımcılarla gerçekleştirilen görüşmelerden elde edilen veriler, araştırmacı tarafından içerik analizi yöntemi ile çözümlenmiştir. Nitel veri çözümlemede içerikleri keşfetmeye yönelik analiz için kodlama, ilk ve aslî bir işlemdir (Punch, 2005, s. 193). İçerik analizi, birbirine benzeyen verileri, belirli kavramlar ve temalar çerçevesinde bir araya getirmek ve bunları anlaşılabilir bir biçimde yorumlamaktır (Yıldırım ve Şimşek, 2013). 
Araştırmanın veri kodları, amaca uygun sorular ile ilişkilendirilerek önce kategorilere ayrılmış ardından temalandırılmıştır. Miles ve Huberman (2015) analiz sürecini, kodların gözden geçirilmesi, işlenmeyen kodların atılması veya kimi kodların geliştirilerek alt kodlara bölünmesini gerektiren bir süreç olarak betimlemektedir. Katılımcıların görüşlerini yansıtan temalar, doğrudan alıntılarla araştırmacı tarafından yorumlanmıştır. Araştırmada verilerin geçerlik ve güvenirliğini sağlamak için inandırıcılık, tutarlık ve teyit edilebilirlik ölçütlerinden yararlanılmıştır. Araştırmacı da projenin katılımcıları arasındadır. Böylelikle araştırmacı, katılımcıların proje sürecindeki deneyimlerini gerçek ortamlarında gözlemlemiş ve katılımcıların araştırma sürecindeki söylemlerini eylemleri ile ilişsilendirebilmiştir. Katılımcılarla yapılan görüşmeler ve gözlemler verilerin yorumlanmasında kullanılarak araştırmanın iç geçerliliği (inandırıcılığı) yükseltilmeye çalışılmıştır. Ulaşılan sonuçlar ortaya konulan verilerle açık bir biçimde ilişkilidir. Bu durum araştırma bulgularının kendi içinde tutarlı olduğunu göstermektedir. Örneğin; katılımcıların gençlik çalışanı olma rollerini yenilikçi, gönüllü olarak betimlemesi ile proje deneyimleri sonucunda yeni dijital uygulamaları ögrenmesi ve bunu mesleki yaşamında kullanmak istemesi bu duruma örnek gösterilebilir. Ulaşılan veriler, katılımcılar ile paylaşılarak verilerin doğruluğu teyit edilmiştir.

\section{BULGULAR}

Erasmus + Projesinde gençlik çalışanı rolünde öğretmen olmayı konu edinen ve öğretmenlerin algılarını görüşmeler yoluyla anlamaya çalışan bu araştırmada, katılımcıların deneyimlerine ilişsin iki tema ortaya çıkmıştır. Araştırma bulguları; gençlik çalışanı rolü ve mesleki gelişim temaları biçiminde katılımcıların deneyimlerini yansıtan görüşlerle aşağıda açıklanmıştır. Araştırma bulguları, proje sürecinde çekilen fotoğraflar ile desteklenmiştir.

\subsection{Gençlik Çalışanı Rolü}

Katılımcı öğretmenler, proje sürecindeki gençlik çalışanı rollerini, beş tema başlığı ile açıklamıştır. Katılımcılar, proje sürecinde kendilerini çoğunlukla gönüllü, hareketli, eleştirel, öz güveni yüksek ve yenilikçi özellikleri ile betimlemiştir. Katılımcıların gençlik çalışanı olarak durumlarını betimleyen roller Şekil 2'de verilmiştir. 


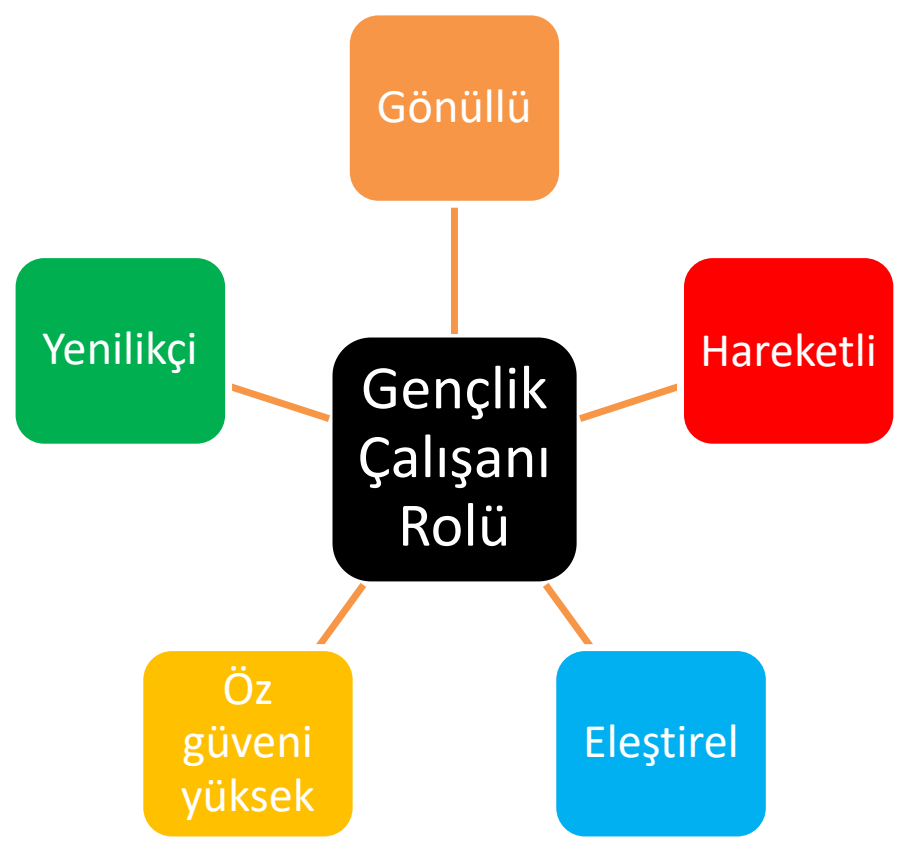

Şekil 2: Katılımcıların gençlik çalışanı olma rolleri

\subsubsection{Gönüllüi}

Katılımcılar, projenin gönüllülük esasına bağlı bir öğrenme hareketliliği olduğunu ve projeye katılanların da etkinliklere gönüllü olarak katıldıklarını ifade etmişlerdir. Katılımcılardan Angela, "Buraya isteyerek geldim. Tüm etkinliklere katılmak ve yeni arkadaşlıklar kurmak için can atıyorum." açıklamasıyla gönüllü bir gençlik çalışanı olduğunu ifade etmiştir. Diğer katılımc1 Paul ise gönüllülük durumunu şöyle açıklamıştır. "Buradaki herkes projenin amacına ulaşması için etkinliklere katıllyor. İstek ve özveri olmasa proje bu kadar dolu olmazdl." Kat1lımc1lardan Constantin, "Kültür gecesi etkinlikleri ve bu etkinliklerde katılımcıların birbirlerine olan ikramları, katılımcıların ne kadar gönüllü olduklarını gösteriyor.” söylemi ile gönüllülük durumunu açıklamıştır. Katılımcıların ifadelerinden onların kendilerini gönüllü bir gençlik çalışanı olarak betimledikleri görülmektedir.

\subsubsection{Hareketli}

Katılımcılarla yapılan görüşmelerde, öğretmenlerin projede sürekli olarak etkinlik yaptıkları ve neredeyse uyku dışında günün büyük bölümünü hareketli bir biçimde geçirdikleri anlaşılmaktadır. Hasan, hareketlilik tanımını şöyle açıklamıştır. "Bu benim ikinci projem. Sürekli etkinlik yapıyoruz. Öyle ki dinlenirken bile energizer [enerjilendiren] isimli kısa zamanlı eğitsel ama çok hareketli etkinliği yapıyoruz. Nasıl bir dinlenme etkinliği hiç anlamadım." Hasan Öğretmen projede sürekli etkinlikler gerçekleştiğinden gençlik çalışanı olmayı, hareketli olma özelliği ile betimlemiştir. Laura, kendini hareketli olarak tanımlama sürecini şöyle betimlemiştir. "Zaman çok hızlı geçiyor, Romanya' ya geldiüim günden beri sürekli bir koşturmaca. Otel salonunda, bahçesinde, sürekli etkinlik yapıyoruz. Bence çok hızl, hareketli ve enerjik” Katılımcıların doğada yaptıkları bir etkinlik anı Görsel 1'de verilmiştir. 


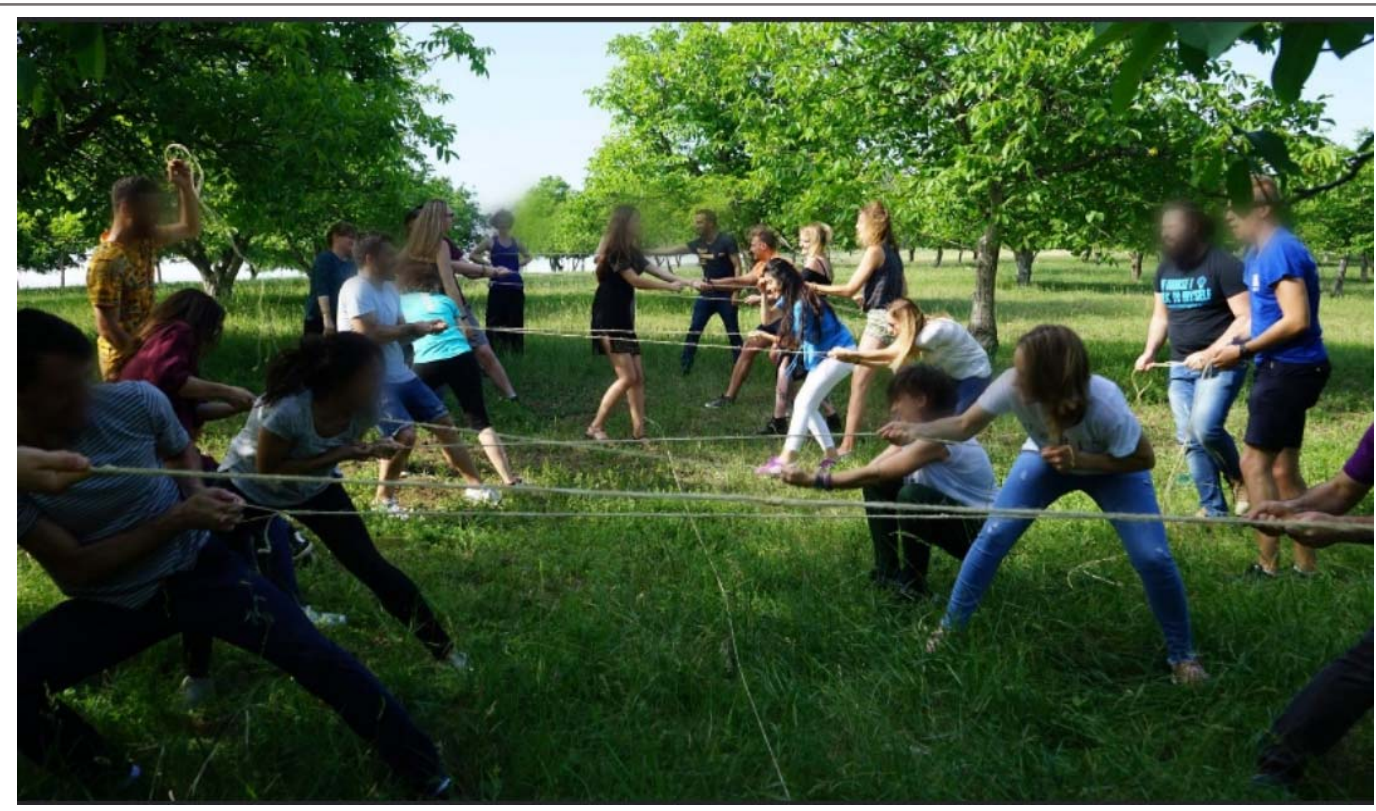

Görsel 1: Katılımcıların doğa ortamından bir etkinlik anı

Constantin ise en hareketli zamanın kültür gecelerindeki yöresel dans anı olduğunu şöyle ifade etmiştir. "Bence kültürel danslar çok güzel. Hareketli danslar çok farkl. Bir yandan hızlı hareketlerle ritme ayak uydurmaya çalışıyorsunuz bir yandan da farkında olmadan yeni bir dans ögrreniyorsunuz." Kısaca, katılımcılar, proje sürecinin hızlı geçtiğini, kendilerinin de gençlik çalışanı olarak çok hareketli biri olduklarını ve bu süreçte gizil öğrenme gerçekleştirdiklerini ifade etmişlerdir.

\subsubsection{Eleştirel}

Katılımcılar, proje sürecinde özeleştiri ile birlikte kurs deneyimlerini de eleştirdiklerini ifade etmişlerdir. Ekinliklerde sorumluluk alma, verilen rol ve görevleri yerine getirme gibi durumlarda katılımcıların süreci gözlemledikleri ve gün sonunda bir araya gelerek kurs gününü değerlendirdikleri gözlemlenmiştir. Paul, "Etkinlikler bence çok önemli, bu nedenle özgün ve yaratıcı olmalıyız. Gün sonunda senin çalışman berbattı sözünü duymak istemem" söylemi ile gençlik çalışanı olmanın eleştirel yönünü betimlemiştir. Angela, "Gün sonunda bazen birbirimizin etkinlikleri hakkinda değerlendirmelerde bulunuyoruz. Bence gençlik çalışanı olan herkes aynı zamanda bir eleştirmen" açıklaması ile gençlik çalışanlarının eleştirel kimlikleri olduğunu ifade etmiştir. Katılımcıların kurs etkinlikleri sonunda otel bahçesinde etkinliklerini eleştiri anı Görsel 2'de verilmiştir. 


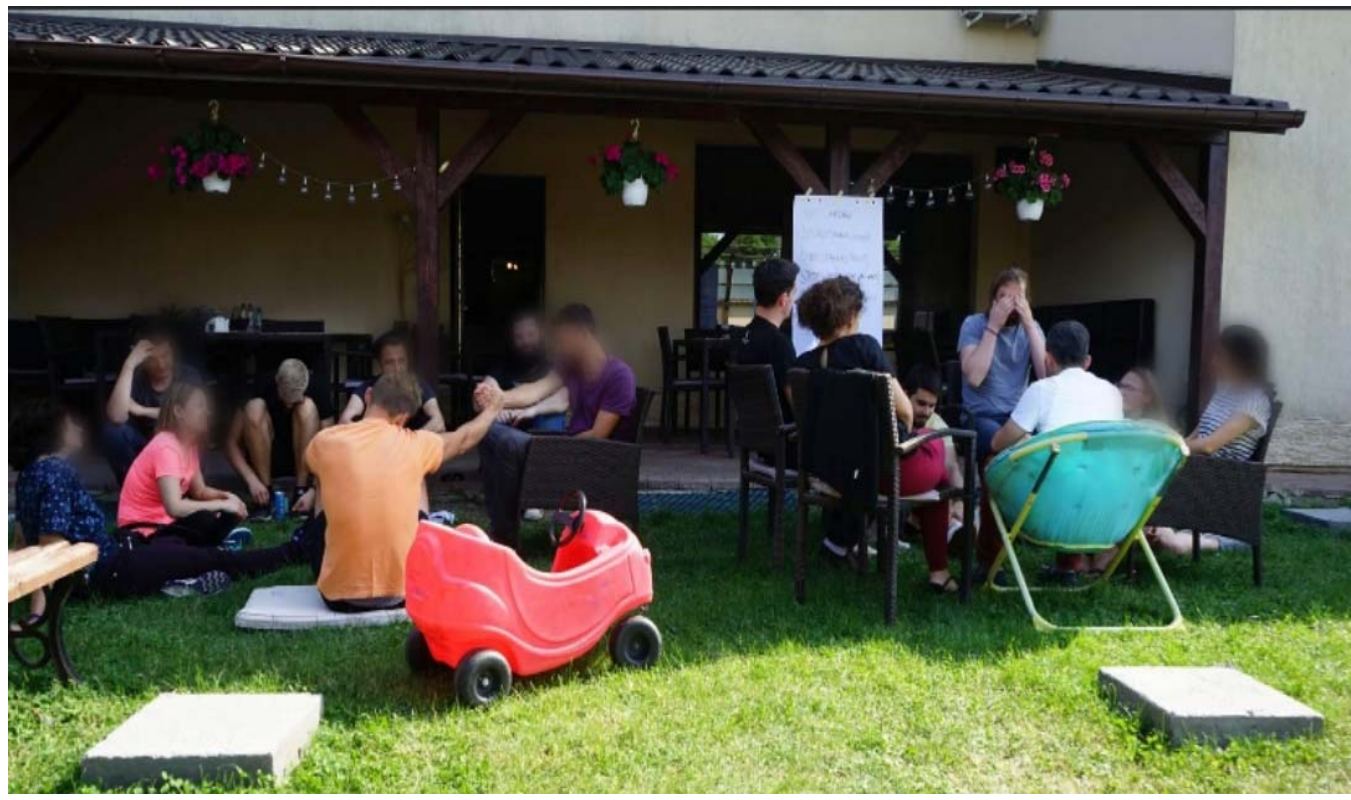

Görsel 2: Katılımcıların gün sonunda etkinliklerini eleştirme anı

Katılımcılardan Marco, "Bazı etkinlerde her ülkeden sadece bir kişi gruba dâhil oluyor. Ülkemi en iyi şekilde temsil etmek isterim. Bu yüzden hep daha iyisini düşünüyor ve analiz ediyorum." Katılımcılar, gün sonunda yaptıkları etkinliklerin analizini gerçekleştirdiklerini ve bu nedenle proje sürecini de eleştirel bir bakış açısıyla değerlendirdiklerini ifade etmişlerdir. Ayrıca kimi katılımcıların eleştirmen olduğu kadar rekabetçi bir tutum da sergilediği görülmüştür.

\subsection{4. $\ddot{O}_{z}$ güveni yüksek}

Katılımcı öğretmenler, dilini ve kültürlerini bilmedikleri başka bir ülkeye gelmişlerdir. İki katılımcı, proje sayesinde ilk yurtdışı çıkışlarını gerçekleştirdiklerini ifade etmiştir. Kimi katılımcılar, bu nedenle her ne kadar temel ve orta düzeyde İngilizce bildiklerini belirtseler de dilini bilmedikleri bir ülkeyi ziyaret etmenin onlar açısından endişeli bir durum olduğunu açıklamıştır. Angela, "Daha önce Romanya'ya gelmedim. Konaklayacağım yeri bilmediğimden ilk başlarda biraz tedirgin oldum. Marco "Bu benim ilk yurt dışı çıkışım, İngilizcem çok iyi olmadığından ve otel yerini bulamazsam parasız kalırım diye korktum. Ama öz güven de böyle kazanılıyor." söylemi ile yaşadığı endişe ve öz güven arasındaki ilişkiyi açıklamıştır. Hasan ise "Daha önce Ingiltere'ye gitmiștim. Bu ve benzer projeler ile bence kişinin kendine olan güveni artıyor." açıklaması ile bu tür projelerin öz güveni artırdığını ifade etmiştir.

\subsubsection{Yenilikçi}

Katılımcılar, proje öncesinde birbirlerinin ülkeleri hakkında yeterli bilgi sahibi olmadıklarından projedeki deneyimlerinin kendilerine bu bağlamda yeni bilgiler ve değerler kazandırdığını ifade etmişlerdir. Katılımcıların söylemlerinden yeni insanlar ve kültürler tanıyarak zihinlerinde birçok yenilik oluşturduğu ve bakış açılarını da değiştirdikleri anlaşılmaktadır. Öyle ki Hasan bu yeniliği "Uluslararasılaşma noktasında kendimi geliş̧tirdim. Farklı insanları tanıyınca bakış açınız değişiyor ve ön yargılarınızı yok ediyorsunuz." söylemiyle açıklamıştır. Paul, "Birçok ülkede projeye katıldım. Bence 
gezerek ögrenmek çok güzel. Kendinizi sürekli güncelliyorsunuz, yeni yerler, insanlar ve hayatlar" ifadesiyle proje deneyimleri ile kendisini sürekli yenilediğini ifade etmiştir. Angela ise yeniliğin farklı kültürleri, dinleri, insanları tanımadan mümkün olmadığını ve öğretmen olan herkesin yeniliklere de açık olması gerektiğini şöyle açıklamıştır. "Proje münazarında savaş olan bir ülkedeki insanları kendi ülkemize alıp almama konusunda tartıştık. Katılımcı ülkelerin farklı bakış açıları benim de düşüncelerimi etkiledi. Bu nedenle yenilik, farklı insan tanımadan çok daha fazlası" Angela, gençlik çalışanı olan katılımcıların proje ile sadece yeni dans ve kültürleri öğrenmediğini bakış açılarında da yeni düşüncelere sahip olabileceğini ifade etmiştir.

\subsection{Mesleki Gelişim}

Katılımcılarla yapılan görüşmeler sonucunda öğretmenler, proje deneyimlerinin mesleki gelişime olumlu yönde katkı sağladığını düşünmektedir. Katılımcılar, projenin mesleki gelişimlerine katkılarını; yabanc1 dil öğrenme, eğlenceli öğrenme, dijital öğrenme, informal öğrenme ve işbirlikli öğrenme temaları ile açıklamışlardır. Ulaşılan alt temalar Şekil 3’te verilmiştir.

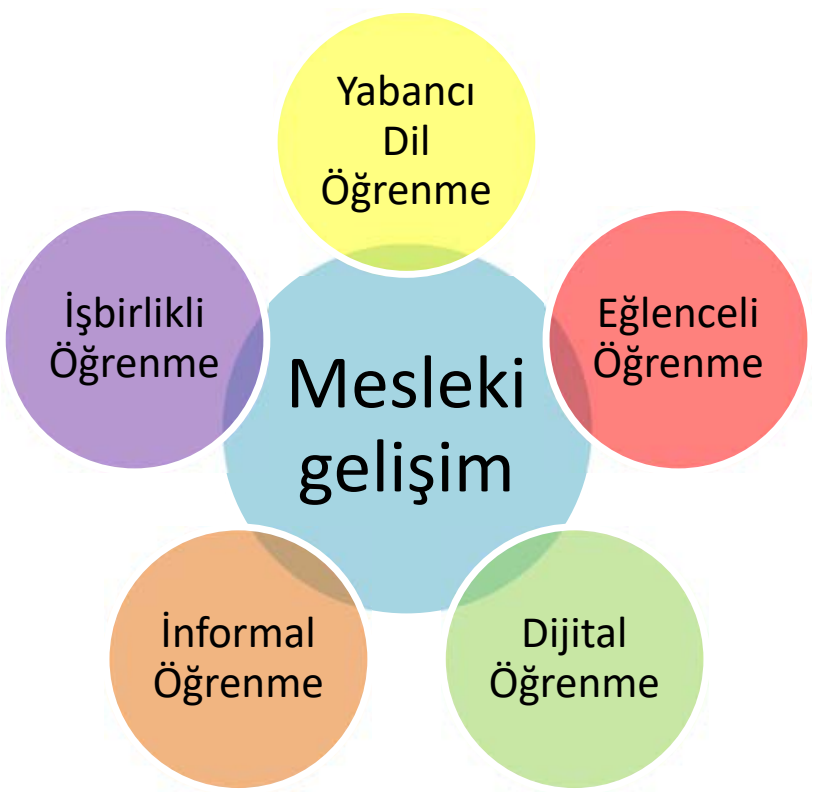

Şekil 3: Projenin mesleki gelişim katkıları

\subsubsection{Yabancı dil öğrenme}

Öğretmenler, görüşmelerinde projede her ülkeden katılımcı olduğunu ve bu durumun onların yabancı dil öğrenme isteğini artırdığını ifade etmişlerdir. Öğretmenler, projenin öğrenme çıktıları olan iletişimsel metot ve etkinlikler ile birlikte temel seviyede İngilizce dışındaki yabancı sözcükleri de öğrendiklerini şöyle açıklamıştır. Laura "Muhteşem bir etkinlik. Her sabah salondaki yazı tahtasına her ülkenin dilinde "Günaydın" veya selamlama anlamına gelen "Merhaba” sözcügünün karşıllğını yazlyoruz. Herkes kendi ülkesi dışındaki sözcükle diğer arkadaşını selamlıyor ve böylelikle her dilde en çok kullanılan basit sözcükleri öğrenmiş oluyoruz." Kimi katılımcılar projenin İngilizce dilinin gelişimine firsat sunduğunu ve projedeki etkinlikler ile İngilizce konuşma becerilerini artırdıklarını da ifade etmişlerdir. Hasan, projenin yabancı dil öğrenime katkısını şöyle betimlemiştir: "Projede sunumlar 
yapıyoruz. Bazen de panel etkinliği düzenliyoruz. Proje dili Ingilizce ancak kimi zaman katılımcıların ana dilinde ifadeleri olabiliyor ve ne demek istediklerini jest, mimikleri ile anlamaya çalışlyoruz. Ama gerçek şu ki projede İngilizce konuşma becerinizi geliştirebiliyorsunuz." Angela ise "Ben Ingilizce ögretmeniyim ve yabancı dillere karşı merakım var. Bu nedenle projede boş kaldığımız zamanlar diğer ülke katılımcıların dilini öğrenmek için onlarla konuşmaya çalışıyorum." söylemi ile proje sayesinde yabancı dil öğrenmeye çalıştı̆̆ını açıklamıştır. Ayrıca katılımcılar, projede kazandıkları deneyimleri ülkelerindeki sınıf ortamlarında da uygulayabileceklerini ifade etmişlerdir.

\subsection{2. Ĕ̆lenceli öğrenme}

Katılımcılar, projeyi uygulamalı etkinlikler ile gerçekleştirdikleri için öğrenmenin çok eğlenceli olduğunu açıklamışlardır. Paul "Az önce çok ciddi bir sunum yaparken hemen ardından bir takside müşteri olan ögrenci grubunu canlandırabiliyoruz. Bu öyle renkli bir ortam ki hiç sıkllmıyoruz. Daha da önemlisi eğlenirken yeni öğretim tekniklerini de öğrenmiş oluyoruz.” Katılımcıların doğaçlama etkinliğini gösteren kare Görsel 3’te verilmiştir.

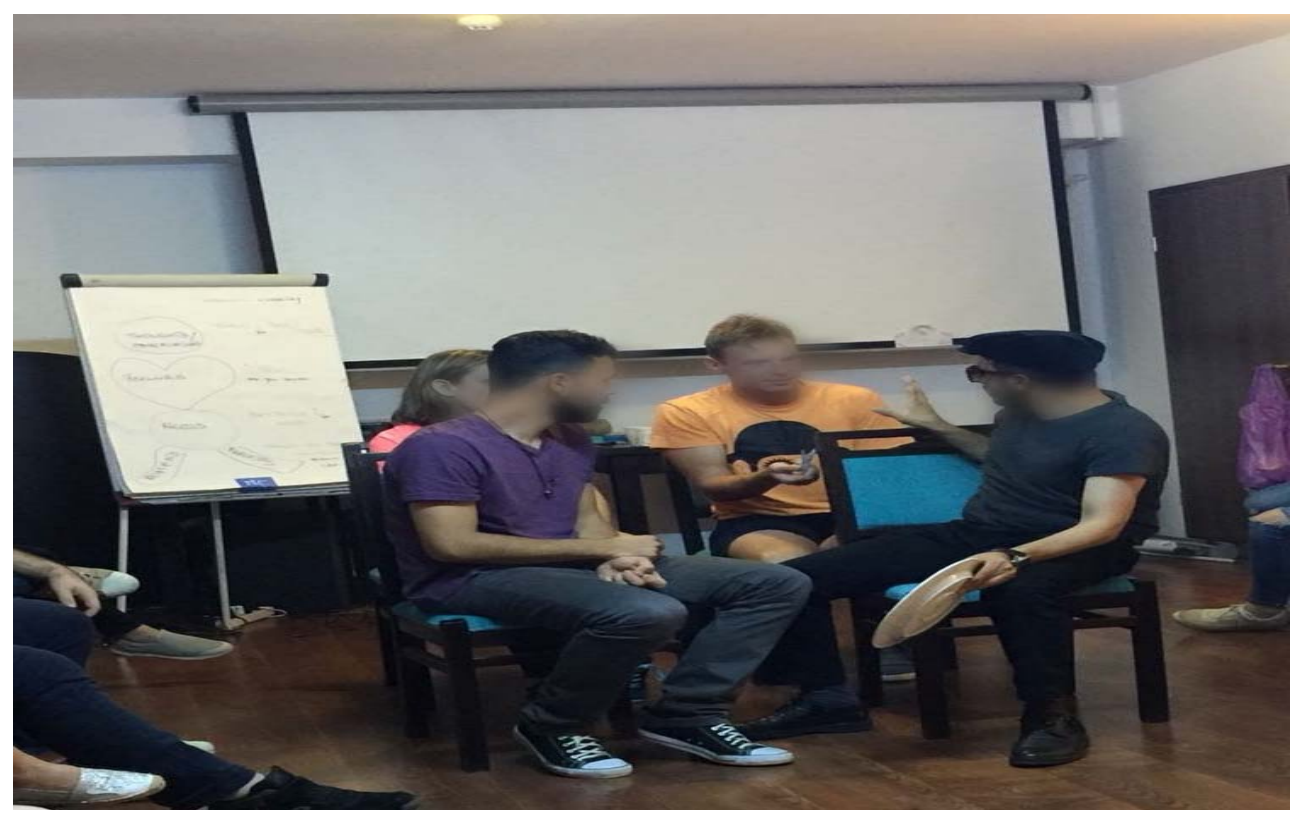

Görsel 3: Katılımcıların doğaçlama etkinliği

Laura ise projenin eğlenceli bir öğrenme ortama dönüşümünü şöyle açıklamıştır. "Kültür gecelerinde her ülke grubu, kendi ülkesini; dansl, yemeği ve giyimi ile tanıttyor. Kendinizi o ülkede gibi hissediyor ve diğer ülkeleri de onların etkinliklerine katılarak tanıma firsatı buluyorsunuz, çok ĕglenceli değil mi? Bu etkinlikleri okullarda tüm çocuklara yaptırmalıyız." Ayrıca katılımcılar, otel dışında geziler düzenleyerek şehrin kültürünü, tarihini öğrendiklerini ve bu öğrenme sürecini de eğlenceli bulduklarını ifade etmişlerdir. Marco, "Projenin artı yanlarından biri de doğada etkinlikler yapmanın yanı sıra şehri öğrenmek için düzenlenen kısa kültür turları. Hem eğlenceli hem faydal." söylemi ile öğrenmenin çok yönlü işlevini vurgulamıştır. 


\subsubsection{Dijital öğrenme}

Proje etkinliklerinde katılımcılar, proje konusu olan iletişimsel metot öğretimini teknoloji tabanlı uygulamalar ile gerçekleştirebiliyor veya katılımcıların proje hakkındaki düşüncelerini bilgisayar ortamında tasarladıkları bir dijital posterde yansıtabiliyordu. Katılımcıların dijital tabanda oluşturdukları ve proje deneyimlerini yansıttıkları poster Görsel 4'te verilmiştir.

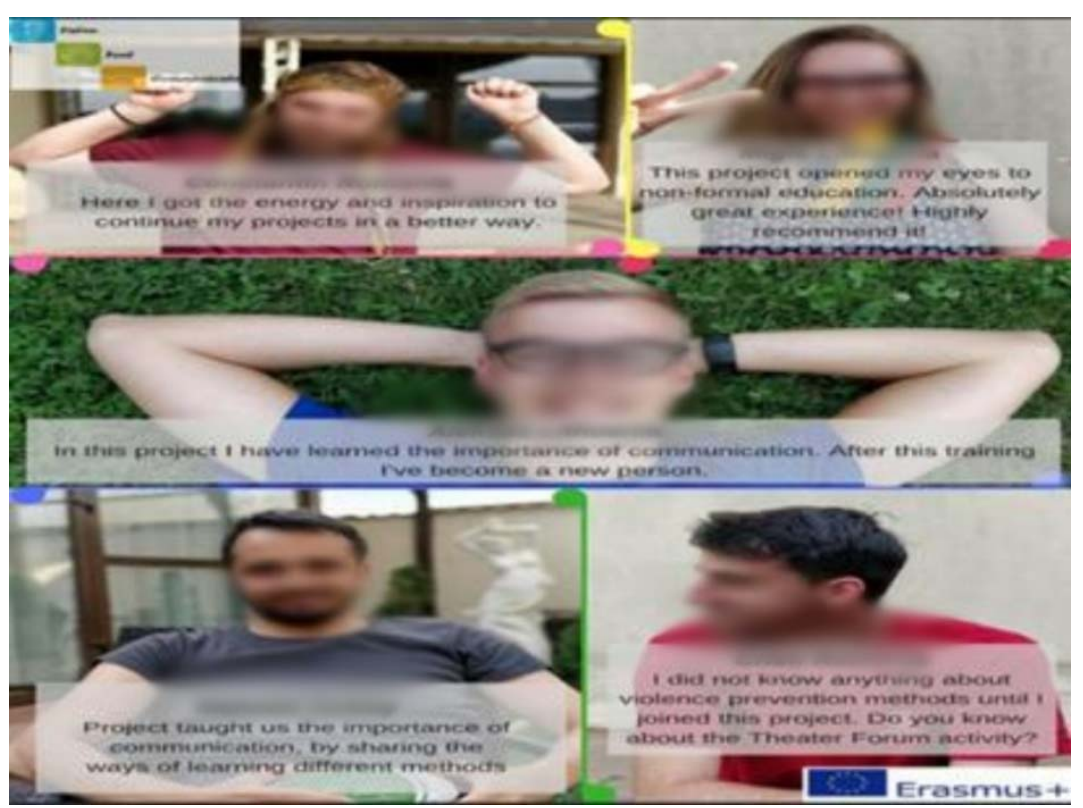

Görsel 4: Katılımcıların proje ile ilgili düşüncelerini yansıtan poster

Laura, "Çocukların okul öğrenmelerinde de buna benzer dijital posterler hazırlanabilir." söylemi ile dijital öğrenmenin okul etkinlikleri açısından önemine değinmiştir. Katılımcılar, proje sürecinde kullandıkları "Kahoot" adlı uygulama ile yeni bir teknolojik uygulamayı tanıdıklarını ve kullanmaktan keyif aldıklarını ifade etmişlerdir. Kimi katılımcılar, Kahoot uygulamasını daha önce kullanmadıklarını ve uygulamayı projede öğrendiklerini açıklamışlardır. Constantin, " $B u$ çok güzel bir uygulama, ülkeleri özellikleri ile tanlyor ve sorulan sorulara verilen cevaplarla birinci ülke grubunu seçiyoruz. Çok keyifli. " ifadesiyle uygulamanın kullanışlı olduğunu açıklamıştır. Kahoot uygulamasında hazırlanılan sorular ile ülke grupları dijital ortamda birbirleri ile yarışabiliyorlardı. Marco "Bu uygulama ile hazırlanan sorularla çocuklara sınıf içinde bilgi yarışları düzenlenebilir." ifadesi ile uygulamanın öğretmenlerin mesleki gelişimi açısından önemini açıklamıştır.

\section{4. İnformal öğrenme}

Katılımcılar, Erasmus projelerinin yaşam boyu sürdüğünü ve kendini geliştirmek isteyen herkesin bu projelere başvurabileceğini ifade etmişlerdir. Ayrıca kimi katılımcılar, öğrenmelerinin değişik zaman ve mekanlarda gerçekleştiğini ve herkesin sürece etkin biçimde katılabildiğini açıklamıştır. Paul, "Yll içinde çok fazla proje yayımlaniyor, isteyen istediği projeye katılarak kendini mesleki yönden geliştirebilir." Hasan, "Iletiş̧im konusunu informal biçimde öğrenmek sanırım daha etkili" söylemi ile informal öğrenmenin mesleki gelişim ile ilişkisini açıklamıştır. Marco oda arkadaşları ile birlikte konaklayarak kurs saati sonrasında da farklı kültürlere ait bilgisini artırdığını ve öğrenmenin kursun her 
anında devam ettiğini şöyle açıklamıştır: "Katılımcılar proje süresince her biri farklı ülkeden hem cinsi olan bir katılımcı ile aynı odayı paylaşıyorlar. Odada bir yabancı. Bu da bir informal öğrenme değil $m i$ ?" Katılımcılar, mesleki gelişimde uluslararası düzenlenen informal etkinliklerin önemli olduğunu düşünmektedir.

\section{5. İşbirlikli öğrenme}

Katılımcılar, kimi zaman kendi ülke grupları ile kimi zaman da farklı ülke katılımcıları ile bir araya gelerek proje etkinliklerini gerçekleştirmişlerdir. Katılımcılar, her ülkeden bir katılımcının seçildiği küçük gruplarda çalışmanın ve iş birliğinin mutluluğunu şöyle betimlemiştir. Angela, "Farklı kültürlerin bir araya geldiği küçük gruplarda birbirimizle yardımlaşmak çok güzel. Doğaçlama yaptığımız gösterilerde, birimiz Flamenko dansını oynarken diğeri Türk çayı içiyor ve bir başka katılımcı Italyan aktörü canlandırabiliyor." Laura, projenin katılımcılara iş birliğinin olumlu sonuçlarını gösterme fırsatı sunduğunu şu sözlerle açıklamıştır. "Proje kazanımlarımızı proje sürecinde bölge okulları ziyaret ederek oradaki ögrencilere aktarlyoruz. Bu bize farklı bir ülkedeki ögrencilerle de iş birliği yapmamızı sağllyor. Farklı ülke öğrencileri ile bir arada etkinlik yapmak da çok keyifli." Katılımcıların okul gezisinde öğrencilerle birlikte gerçekleştirdikleri etkinlik anı Görsel 5'te verilmiştir.

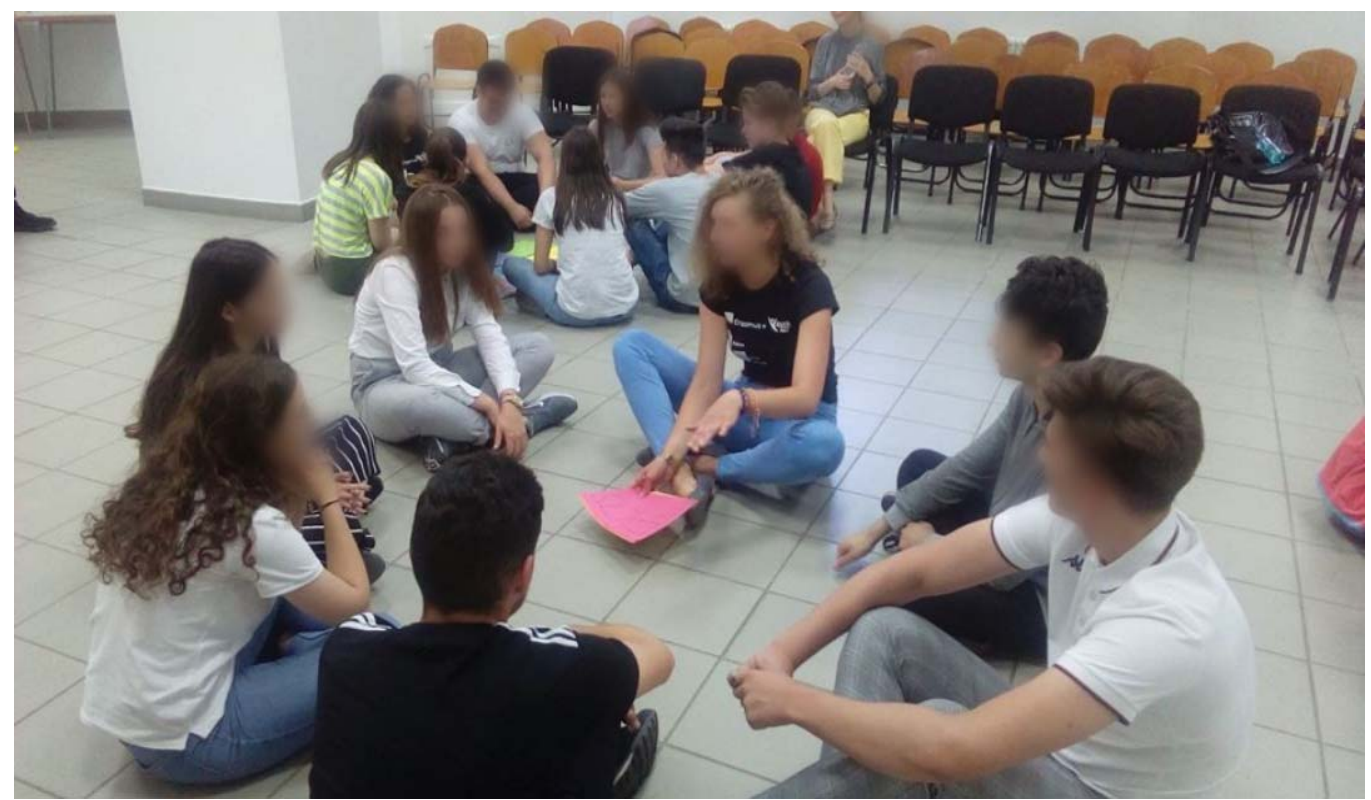

Görsel 5: Katılımcıların Romanya'da bir okul ziyaretinde ögrencilerle etkinlik anı

Laura, proje kazanımlarını Romanya' da gerçekleştirdikleri okul ziyaretlerinde de uyguladıklarını ifade etmiştir. Ayrıca Romanya'daki öğrencilerle birlikte etkinlik yapmanın da mesleki açıdan çok keyifli olduğunu açıklamıştır. Constantin, "Hepimiz yabancı da olsak proje etkinlikleri bizi bir araya getirebiliyor. Öğrencilerle birlikte yaptığımız energizer oyunu bile başlı başına büyük bir başarı" ifadesi ile katılımcıların öğrencilerle birlikte yaptıkları etkinliğin kendileri için büyük başarı olduğunu açıklamıştır. Katılımcıların çoğu, projenin işbirlikli öğrenmeyi desteklediğini, projedeki etkinliklerin sosyal medya aracılığı ile paylaşılmasını ve ülkelere dönüşte öğrencilere uygulanması gerektiğini ifade etmiştir.

Anadolu Üniversitesi Ĕgitim Fakültesi Dergisi (AUJEF), 5(4), 427-446. 


\section{TARTIŞMA ve SONUÇ}

Erasmus + projesine katılan öğretmenlerin deneyimlerine ilişkin genel görüşleri incelendiğinde katılımcıların gençlik çalışanı olarak kendilerini tanımlamaları ve mesleki gelişimleri bağlamında kimi sonuçlara ulaşılmıştır. Araştırmada katılımcı öğretmenler, kendilerini gençlik çalışanı olarak gönüllü, eleştirel, hareketli, öz güveni yüksek ve yenilikçi olarak betimlemişlerdir. Katılımcıların proje ile süreçteki etkinliklere gönüllü olarak dâhil oldukları, etkinlikleri ve kendilerini eleştirel bir bakış açısıyla değerlendirdikleri anlaşılmaktadır. Ayrıca araştırmada katılımcıların proje sürecindeki etkinliklerden dolayı çok hareketli bir yapıda oldukları ve kimi katılımcıların dilini, kültürünü bilmediği bir ülkeye giderek öz güvenini artırdığı sonucuna ulaşılmaktadır. Dolga vd.,(2015), Erasmus programı ile katılımcıların akademik öz güvenlerini yükselttiği, profesyonel bilgi ve becerilerini artırdığı, akademik kimliklerini geliştirdiği sonuçlarına ulaşmıştır. Katılımcıların anlatılarından projenin öğretmenlerin kişisel gelişimlerini de olumlu yönde etkilediği söylenebilir. Proje deneyimleri, kimi katılımcıların farklı kültürleri yakından tanımasına olanak sunmuş ve ön yargılarını yıkarak onlara yenilikçi bir bakış açısı kazandırmıştır. Alanyazın değerlendirildiğinde bu bulguyu araştırma grubu üniversite öğrencileri olan benzer çalışmalar da desteklemektedir. Ersoy ve Öncül (2016) çalışmalarında doktora öğrencilerinin Erasmus Yoğun Program deneyiminin İngilizce konuşma ve yazma becerilerini geliştirme, kariyer firsatları sunacak kişilerle tanışma ve araştırma kültürünü kazandırma bakımlarından yararlı buldukları sonucuna ulaşmıştır. Yine birçok araştırmada, uluslararası projelerin projeye katılan kişilere uluslararası ağ oluşturma firsatı sunduğu ortaya konulmuştur (Beerkens ve Vossensteyn, 2011; Chiang, 2003; Dolga vd., 2015; Vural, Polatoğlu ve Griffith, 2013).

Araştırmada, proje etkinliklerinin öğretmenleri mesleki açıdan geliştirdiği sonucuna da ulaşılmıştır. Katılımcı öğretmenler, farklı ülkelerden gelen katılımcılar sayesinde İngilizce dışında günlük yaşamda sıç̧a kullanılan farklı dillerin sözcüklerini de öğrendiklerini belirtmişlerdir. Papatsiba (2005), Şahin (2007), Ünal (2011), Yağc1 vd. (2007) yapmış oldukları araştırmalarda da benzer sonuçlara ulaşmıştır. Bu araştırmalara katılan öğrencilerin, proje etkinlikleri ile en çok yabancı dil becerisini geliştirdikleri ve yeni kültürleri tanıyarak yaşama bakış açılarını değiştirdikleri sonucuna ulaşılmıştır. Demir ve Demir (2009) tarafından yapılan çalışmada da üniversite öğrencilerinin farklı ülkeleri görme, değişik kültürleri tanıma, yabancı dil ve akademik gelimlerine katkı sağlama amacıyla programa katıldıkları ifade edilmiştir. Araştırma, öğretmenlerin projede istenen yabancı dili bilmenin Erasmus projeleri açısından önemli olduğunu da ortaya koymaktadır. Proje dili İngilizce olduğundan kimi katılımcılar, proje ile İngilizce konuşma becerilerini de geliştirebileceklerini savunmaktadır. Akademisyenler için İngilizcenin uluslararası projeler aracılığıyla geliştiğine ilişkin araştırma sonuçları bulunmaktadır (Conrad ve Mauranen, 2003; Engel, 2010; Kotzabassaki vd., 2003; Krzaklewska ve Krupnik, 2008; Seidlhofer, 2005). Katılımcılar, proje sürecindeki eğlenceli etkinlikler ile farklı ülkelerin danslarını öğrenmiş, dijital uygulamalar hakkında bilgi sahibi olmuş ve bu uygulamaları kullanmışlardır. Ayrıca, bulgulardan Erasmus projeleri ile her öğretmenin kendini mesleki açıdan geliştirebileceği ve informal öğrenmeler ile yeni öğrenmeler gerçekleştirebileceği anlaşılmaktadır. Katılımcılar, proje kazanımlarını gittikleri okul ziyaretlerinde öğrencilere aktararak işbirlikli öğrenme gerçekleştirmiş ve bu deneyimlerini mesleki gelişimleri açısından önemli görmüşlerdir. Araştırma sonucunda katılımcı öğretmenlerin, proje kazanımlarını kendi okul uygulamalarında da deneyimlemek istediği anlaşılmaktadır. Rosenjack (2002) da değişim programları ile öğrencilerin proje süresince eğitim ortamlarında edindikleri bilgi ve becerilerin onların gelecekteki mesleki becerilerini bireysel olarak geliştireceğini ve kurulan sosyal bağın da uluslararası bilgi paylaşımına katkı sağlayacağını savunmaktadır. 
Araştırma bulguları alanyazın bağlamında değerlendirildiğinde katılımcıların Erasmus + bireysel öğrenme hareketliliği kazanımlarından birçoğuna ulaşabildiği anlaşılmaktadır. Katılımcılar, proje sayesinde uluslararası bakış açısı kazarak kişisel ve mesleki gelişimlerini geliştirme fırsatını bulmuşlardır. Alanyazında kimi araştırma sonuçları da bu çalışmanın sonuçlarını destekler niteliktedir. Elmalı (2013), Kağnıcı (2016), Özdem (2013) ve Ünal (2011) da araştırmalarında benzer bulgulara ulaşmış; Erasmus kapsamındaki programların katılımcılara sosyal, kültürel, bireysel ve mesleki katkılar sunduğunu belirtmişlerdir. Avrupa Birliği Bakanlığı (2017) tarafından yapılan çalışma da bu araştırmanın sonuçlarını desteklemektedir. Bakanlık tarafından yapılan çalışmada Erasmus + programının yeterlilik ve becerileri geliştirme, çokdillilik ve uluslararasılaştırma hedeflerine hizmet ettiği belirtilmiştir. Araştırma sonuçları bağlamında aşağıdaki öneriler sunulabilir.

- Uluslararası gerçekleştirilen informal projeler artırılabilir.

- Katılımcılar, kazanımlarını proje sonrasında kendi ülkelerinde tanıtarak yaygınlaştırabilir.

- Proje etkinliklerine katılımın artması için katılımcıların İngilizce seviyelerini geliştirmeye yönelik çalışmalar yapılabilir.

- Alanyazındaki çalışmalarda üniversite öğrencileri dışında öğretmen ve diğer meslek gruplarını da kapsayacak biçimde araştırma grubu oluşturulabilir ve onların da deneyimlerini yansıtacak araştırmalar gerçekleştirilebilir. 


\section{KAYNAKLAR}

Absalom, R. (1990). Practical rather than declamatory co-operation: Erasmus in 1990, an appraisal, European Journal of Education, 25(1), 39-54.

Akturan, U. ve Esen, A. (2008). Fenomenoloji. T. Baş ve U. Akturan (Ed.), Nitel araştırma yöntemleri içinde (s. 83-98). Ankara: Seçkin Yayıncılık.

Avrupa Birliği Bakanlığı. (2017). National Report of TURKEY on the implementation and the impact of Erasmus+ and Predecessor Programmes: Lifelong Learning, Youth in Action. Ankara. Retrieved from https://ec.europa.eu/programmes/erasmusplus/sites/default/files/el_national_report/TR_National\%20Repo rt.pdf. (Erişim tarihi:14.08.2021)

Beerkens-Soo, M., \& Vossensteyn, J. J. (2011). The Effect of the ERASMUS Programme on European Higher Education: The Visible Hand of Europe. In J. Enders, H. F. de Boer, D. F. Westerheijden (Eds.), Reform of Higher Education in Europe (pp. 45-62). Sense Publishers.

Cervelló Collazos, J. and Guardia González, S. (2008). Évaluation de la satisfaction des étudiants européens ayant participé au programme R.E.S.O. In M. J. Berger \& R. Forgette-Giroux (Eds.), Bilan et perspectives. Coopération entre l'Union européenne et le Canada dans la formation des enseignantes et des enseignants. (pp. 55-67): [Brossard?]: Éditions La Périchole.

Chiang, K. H. (2003). Learning experiences of doctoral students in UK universities. International Journal of Sociology and Social Policy, 23(1/2), 4-32.

Conrad, S. and Mauranen, A. (2003). The corpus of English as lingua franca in academic settings. Tesol Quarterly, 37(3), 513-527.

Declaration, B. (1999). The Bologna Declaration of 19 June 1999. Joint declaration of the European Ministers of Education. European Union, Brussels.

Demir, A. ve Demir, S. (2009). Erasmus programının kültürlerarası diyalog ve etkileşim açısından değerlendirilmesi (Öğretmen adaylarıyla nitel bir çalışma). Uluslararası Sosyal Araştırmalar Dergisi, 2(9), 95-105.

Diana, P., Maddaloni, D., Melillo, L., \& Moffa, G. (2015). Teaching migration studies throughcollaborative learning practices in an intercultural environment: The case of the Erasmus ip IP sono un migrante. ProcediaSocial and Behavioral Sciences, 174, 510-517.

Dolga, L., Filipescu, H., Popescu-Mitroi, M. M. and Mazilescu, C. A. (2015). Erasmus mobility impact on professional training and personal development of students beneficiaries. Procedia-Social and Behavioral Sciences, 191, 1006-1013.

Elmalı, G. G. (2013). Avrupa Birliği Eğitim ve Gençlik Programları'nın Türkiye uygulamasının Erasmus Programı bağlamında değerlendirilmesi (Yayınlanmamış Yüksek Lisans Tezi). Afyon Kocatepe Üniversitesi, Afyonkarahisar.

Engel, C. (2010). The impact of Erasmus mobility on the professional career: Empirical results of international studies on temporary student and teaching staff mobility. Belgeo. Revue belge de géographie, 4, 351-363.

Ersoy, A. (2013). Türk öğretmen adaylarının kültürlerarası deneyimlerinde karşılaştıları sorunlar: Erasmus değişim programı örneği. Eğitim ve Bilim, 38(168), 154-166.

Ersoy, A., ve Günel, E. (2011). Cross-cultural experiences through Erasmus: Pre-service teachers' individual and professional development. Eurasian Journal of Educational Research, 42, 63-78. 
Ersoy, A. ve Öncül, B. (2016). Araştırma yöntemleri denizinde yüzmek: Doktora öğrencilerinin erasmus yoğun program (IP) deneyimleri. Kastamonu Eğitim Dergisi, 25(3), 1203-1220.

European Commission Education \& Training. (2013). History of the ERASMUS Programme. Retrieved from http://ec.europa.eu/education/erasmus/history_en.htm (Erişim tarihi: 09 .07.2021).

EU Programme-Guide (2021). Key Action 1: Learning Mobility of Individuals. Retrieved from https://ec.europa.eu/programmes/erasmus-plus/printpdf/programme-guide/part-b/key-action-1_en (Erişim tarihi: 08.04.2021).

EU Counc1l (2009). Council conclusions of 12 May 2009 on a strategic framework for European cooperation in education and training (ET 2020). Official Journal of the European Union.

Gibbons, M. (1998). Higher education relevance in the 21st century. Presented at the UNESCO World Conference on Higher Education. Washington, DC: World Bank.

Göksu, F. (2011). Bir kültürlerarası iletişim incelemesi: Erasmus Programı ile Avusturya’ya giden Türk öğrencilerin yaşantı ve beklentileri üzerine yapılan odak grup çalışması. İstanbul Üniversitesi, Yayınlanmamış Yüksek Lisans Tezi, İstanbul.

James, C. (2013). Enhancing the QLD: Internationalisation and employability: The benefits of Erasmus intensive programmes. The Law Teacher, 47(1), 64-82.

Jones, H. C. (2005). Lifelong learning in the European Union: Whither the Lisbon strategy? European Journal of Education, 40(3), 247-260.

Kağnıcı, S. (2016). The impact of EU Mobility Programmes on the construction of European identity: A study on Turkish Erasmus Students (Unpublished Master's Thesis). Yaşar University, İzmir.

Kasapoğlu-Önder, R. ve Balcı, A. (2010). Erasmus öğrenci öğrenim hareketliliği programının 2007 yılında programdan yararlanan Türk öğrenciler üzerindeki etkileri. Ankara Avrupa Çalışmaları Dergisi, 9(2), 93116.

Kotzabassaki, S., Alabaster, E. S., And, K., Larsson, U. and Wree, W. (2003). Care of older people in nursing homes: An intensive programme as an educational activity within Erasmus-Socrates. Nurse Education Today, 23(2), 138-145.

Krzaklewska, E. and Krupnik, S. (2008). The role of the Erasmus programme in enhancing intercultural dialogue. Presentation of the results from the Erasmus student network survey 2007. Proceedings of the 4th International Barcelona Conference on Higher Education'da sunulan bildiri. Barcelona.

Maiworm, F. (2001). Erasmus: continuity and change in the 1990s, European Journal of Education, 36(4), 459472.

Miles, B. M. \& Huberman, M. A. (2015). Nitel veri analizi (S. Akbaba Altun ve A. Ersoy Çev. Ed.). Ankara: Pegem Akademi.

Neuman, L. W. (2014). Social Research Methods: Qualitative And Quantitative Approaches (Seventh Ed.). Essex: Pearson Education Limited.

Özdem, G. (2013). Yükseköğretim Kurumlarında ERASMUS Programının Değerlendirilmesi (Giresun Üniversitesi Örneği). Kuram ve Uygulamada Eğitim Yönetimi Dergisi, 19(1), 61-98.

Papatsiba, V. (2005). Student mobility in Europe: An academic, cultural and mental journey? Some conceptual reflections and empirical findings. International Perspectives on Higher Education Research, 3, $29-65$.

Pépin, L. (2007). The history of EU cooperation in the field of education and training: How lifelong learning became a strategic objective. European Journal of Education, 42(1), 121-132. 
Punch, K. (2005). Sosyal araştırmalara giriş: Nitel ve nicel yaklaşımlar (D.Bayrak, B. Aslan ve Z. Akyüz, Trans.). Ankara: Siyasal Kitabevi.

Rosenjack B. J. 1. (2002). Cultural Competence: An Evolutionary Perspective, Nursing Forum, 37(4), 5-15.

Sakar, T. (2009) Avrupa Birliği’nin Sosyal Politika ve İstihdam Alanlarındaki Düzenlemelerine Türkiye'nin Uyumu: Yapısal Bir Değerlendirme, Yayımlanmamış Yüksek Lisans Tezi, Edirne: Trakya Üniversitesi Sosyal Bilimler Enstitüsü.

Seidlhofer, B. (2005). English as a lingua Franca. ELT journal, 59(4), 339.

Smith, J. A., Flowers, P. and Larkin, M. (2009). Interpretative phenomenological analysis: Theory, method and research. Sage Publications.

Şahin, İ. (2007). Perceptıons of turkısh exchange students of the european union's erasmus program (Yayınlanmamış yükssek lisans tezi). Boğaziçi Üniversitesi, İstanbul.

Teichler, U. (2001). Changes of ERASMUS under the umbrella of SOCRATES. Journal of Studies in International Education, 5(3), 201-227.

Ünal, M. (2011). Avrupa birliği Erasmus öğrenci öğrenim hareketliliği programının CIPP (bağlam, girdi, süreç, ürün) modeline göre değerlendirilmesi (Yayınlanmamış doktora tezi). Gazi Universitesi, Ankara.

Ünlü, İ. (2015). Teacher Candidates' Opinions on Erasmus Student Exchange Program. Educational Sciences: Theory and Practice, 15 (1), 223-237.

Vossensteyn, H., Beerkens, M., Cremonini, L., Huisman, J., Souto-Otero, M., Bresancon, B., Focken, N., Leurs, B., McCoshan, A. and Mozuraityte, N. (2010). Improving Participation in the Erasmus Programme. Final Report to the European Parliament.

Vural, S. M., Polatoğlu, Ç., \& Griffith, L. A. (2013). Learning with different cultures in high education; An LLP Erasmus intensive programmed "Cultural Layers of Public Space". Procedia-Social and Behavioral Sciences, 89, 418-421.

Wachter, B. (2003). Internalisation at home in context. Journal of Studies in International Education, 7(1), 5-11.

Yağcı, E., Ekinci, C. E., Burgaz, B., Kelecioğlu, H., \& Ergene, T. (2007). Yurt dışına giden Hacettepe üniversitesi erasmus öğrencilerinin memnuniyet düzeyleri. Hacettepe Üniversitesi Eğitim Fakültesi Dergisi, 33(33), 229-239.

Yıldırım, A. ve Şimşek, H. (2013). Sosyal bilimlerde nitel araştırma yöntemleri (9. Baskı). Ankara: Seçkin Yayıncılik.

Yücel, M. S. (2013). Language and Cultural Experiences of German Language Pre-service Teachers within ERASMUS Programme. Ankara University, Journal of Faculty of Educational Sciences, 46(1), 23-47. 


\section{EXTENDED ABSTRACT}

Today, Europe's mobility by including participants of all age groups is a reflection of globalization. With this mobility, it is thought that European countries provide educational professional development, equal opportunities and opportunities in the field of education. EU countries aim to realize lifelong learning and mobility through project mobility, to improve quality in education and training and to increase its effectiveness. The "Listen, Feel, Communicate" project, in which the participants were involved, was realized as a result of the awareness of the needs of the project partners. The project was hosted by Romania and was attended by Italy, Spain, Lithuania, Romania and Turkey. Five people from each country group participated in the project to represent their country. The project, "Listen, Feel, Communicate", is organized as a course aimed at developing among youth employees, developing their knowledge and skills of different types of communication (verbal, non-verbal, ambitious, nonviolent), adapting the common method of education to the target groups. It was deemed necessary to repeat these studies with different research groups and to describe the project experiences of the teachers. Six teachers participated in the research, two from Spain and one from Italy, Lithuania, Romania and Turkey. In the research, how the teachers participating in Erasmus individual learning mobility project define themselves and the contributions of the project experiences to professional development are described.

In the study, participating teachers described themselves as volunteers, critical, mobile, selfconfident and innovative as youth employees. It is understood that the participants voluntarily participate in the activities in the project and the process, evaluating the activities and themselves from a critical point of view. In addition, the research concludes that the participants are very active due to the activities in the project process and that some participants increase their self-confidence by going to a country where they do not know their language or culture. From the narratives of the participants, it can be said that the project also positively affects the personal development of teachers. Project experiences have allowed some participants to get to know different cultures and have broken down their prejudices, giving them an innovative perspective.

In the study, it was also concluded that project activities improve teachers professionally. The participating teachers stated that they learned the words that are frequently used in daily life besides English thanks to the participants from different countries. The research also reveals that it is important for teachers to know the desired foreign language in the project. Participants learned about the dances of different countries with fun activities in the project process, learned about digital applications and used these applications. In addition, it is understood from the findings that with Erasmus projects, each teacher can develop himself professionally and carry out informal learning and new learning. Participants carried out collaborative learning by transferring the project gains to the students during their school visits.

It is understood from the research that the participating teachers also want to experience the project gains in their own school practices. When the research findings are evaluated in the context of the field, it is understood that the participants were able to reach many of the Erasmus individual learning mobility gains. As a result of the research, it is recommended to increase the informal projects carried out internationally, to promote and expand the project activities of the participants in their own countries after the project, and to learn the project language adequately for effective participation in the project. 